\title{
IMPLEMENTASI PEMBELAJARAN BAHASA JAWA (MATERI TEMBANG DOLANAN) BERBASIS PENDIDIKAN KARAKTER RELIGIUS DALAM KURIKULUM 2013
}

\author{
Prima Veronika, Budhi Setiawan, Nugraheni Eko Wardani \\ Magister Pendidikan Bahasa dan Sastra Jawa \\ Universitas Sebelas Maret Surakarta \\ Email: primaveronika93@gmail.com
}

\section{Abstract}

The aim of this study is to determine the implementation of Javanese language learning (through dolanan song) based on religious character building in curriculum 2013. It employs qualitative research design with a single case study approach. The results showed that the learning of Javanese language (on dolanan song) can establish religious character building through a scientific approach. Its implementation may involve learning models such as role play, discovery learning and problem based learning. The steps of learning based on scientific approach include activities to observe, ask, gather information, associates, try and communicate.

Penelitian ini bertujuan untuk mengetahui implementasi pembelajaran Bahasa Jawa (materi tembang dolanan) berbasis pendidikan karakter religius dalam kurikulum 2013. Jenis penelitian ini adalah penelitian kualitatif dengan pendekatan studi kasus tunggal. Hasil penelitian menunjukkan bahwa pembelajaran Bahasa Jawa (materi tembang dolanan) dapat menanamkan pendidikan karakter religius melalui pendekatan saintifik. Implementasinya dapat menggunakan model pembelajaran Role Playing, Discovery Learning dan Problem Based Learning. Adapun langkah-langkah pembelajaran berbasis 
pendekatan saintifik meliputi kegiatan mengamati, menanya, mengumpulkan informasi, mengasosiasi, mencoba, dan mengomunikasikan.

Keywords: Javanese Learning; Dolanan Song; Character Building Religious; Curriculum 2013

\section{Pendahuluan}

Berbagai fenomena perilaku negatif sering terlihat dalam kehidupan sehari-hari pada anak-anak. Melalui surat kabar atau televisi dijumpai kasus anak usia dini yang berbicara kurang sopan, senang meniru adegan kekerasan, juga meniru perilaku orang dewasa yang belum semestinya dilakukan anak-anak, bahkan perilaku bunuh diri pun sudah mulai ditiru anak-anak. Seperti terlihat pada portal berita online liputan6.com terdapat beberapa headline news terkait dengan kenakalan remaja seperti "Cemburu, ABG Siksa Sahabatnya Hingga Meregang Nyawa", "Miris 6 ABG Makassar Ngelem Saat Sahur di Samping Masjid", "Remaja 14 Tahun Ditahan Karena Meninju Wajah Nenek 87 Tahun”. Kondisi tersebut sangat memprihatinkan mengingat dunia anak seharusnya merupakan dunia yang penuh dengan kesenangan untuk mengembangkan diri, yang sebagian besar waktunya diisi dengan belajar melalui berbagai macam permainan dilingkungan sekitarnya. Salah satu penyebab terjadinya banyak penyimpangan pada anak-anak adalah seringnya mereka melakukan peniruan atau imitasi yang tidak tepat sehingga memunculkan perilaku yang kurang sesuai dengan norma, aturan, dan kaidah agama. Disinilah nilai-nilai pendidikan karakter sangat penting ditanamkan pada diri anak sejak usia dini yang merupakan masa keemasan (golden age).

Penanaman pendidikan karakter bertujuan untuk meningkatkan mutu penyelenggaraan dan hasil pendidikan yang mengarah pada pencapaian pembentukan karakter dan akhlak mulia peserta didik secara utuh, terpadu, dan seimbang. Melalui pendidikan karakter diharapkan peserta didik mampu secara mandiri meningkatkan dan menggunakan pengetahuannya, mengkaji dan menginternalisasi, serta mempersonalisasi nilai-nilai karakter dan akhlak mulia sehingga terwujud dalam perilaku sehari-hari (Muslich, 2011: 81). Sebagai suatu sistem pendidikan, maka dalam pendidikan karakter juga terdiri dari unsur-unsur pendidikan yang selanjutnya akan dikelola melalui bidang-bidang perencanaan, pelaksanaan, dan pengendalian. Unsur-unsur pendidikan karakter yang akan direncanakan, dilaksanakan, dan dikendalikan tersebut antara lain: a) nilai-nilai karakter kompetensi lulusan, b) muatan kurikulum 
nilai-nilai karakter, c) nilai-nilai karakter dalam pembelajaran, d) nilai-nilai karakter pendidik dan tenaga kependidikan, e) nilai-nilai karakter pembinaan kepesertadidikan (Wiyani, 2013: 87).

Dalam Permendikbud Nomor 81a Tahun 2013 dijelaskan bahwa kegiatan pembelajaran merupakan proses pendidikan yang memberikan kesempatan kepada peserta didik untuk mengembangkan potensi mereka menjadi kemampuan yang semakin lama semakin meningkat dalam sikap, pengetahuan, dan keterampilan yang diperlukan dirinya untuk hidup dan untuk bermasyarakat, berbangsa, serta berkontribusi pada kesejahteraan hidup umat manusia. Oleh karena itu, kegiatan pembelajaran diarahkan untuk memberdayakan semua potensi peserta didik menjadi kompetensi yang diharapkan. Adapun implementasi pembelajaran Bahasa Jawa telah tertuang dalam Keputusan Gubernur Jawa Tengah No: 423.5/27/2011 yang menyatakan bahwa Kurikulum Mata Pelajaran Muatan Lokal untuk jenjang pendidikan Sekolah Menengah Atas/ Sekolah Menengah Atas Luar Biasa/ Sekolah Menengah Kejuruan/ Madrasah Aliyah Negeri dan Swasta di Propinsi Jawa Tengah adalah Bahasa Jawa. Program pendidikan muatan lokal mempersiapkan siswa agar mereka memiliki wawasan yang mantap tentang lingkungannya serta sikap dan perilaku bersedia melestarikan dan mengembangkan sumber daya alam, kualitas sosial, dan kebudayaan yang mendukung pembangunan nasional maupun pembangunan setempat.

Dalam penelitian yang dilakukan oleh Arafik (2013) dengan judul "Penanaman Nilai-nilai Moral Melalui Tembang Dolanan Sebagai Alternatif Pendidikan Karakter bagi Anak Usia Dini" dapat diketahui bahwa nilai-nilai moral yang terdapat dalam tembang dolanan dapat dijadikan salah satu sarana alternatif pendidikan karakter bagi anak usia dini. Ciri khas tembang dolanan yang dinyanyikan dalam suasana bermain yang menyenangkan sangat cocok untuk anak. Hasil yang diharapkan dengan mempelajari tembang dolanan adalah anak-anak mampu mengetahui kemudian merasakan dan pada akhirnya berperilaku sesuai dengan nilai-nilai moral yang diharapkan. Sementara itu dalam penelitian yang dilakukan oleh Inayati dan Ahmad (2016) yang berjudul "Islamic Education and Multiple Intelligences Implementation in Traditional Game of Sluku-Sluku Bathok at Komunitas Pojok Budaya, Bantul of Yogyakarta" dapat diketahui bahwa permainan tradisional sluku-sluku bathok tidak hanya membuat anak-anak bahagia, tetapi juga merangsang anak-anak untuk mengembangkan kecerdasan majemuk mereka. Manfaat dapat dilihat dari bergerak dalam permainan, kebersamaan dalam karakteristik permainan,

el Harakah Jurnal Budaya Islam Vol. 19 No.1 Tahun 2017 
serta lagu yang mereka nyanyikan. Selain itu, lagu di sluku-sluku bathok dapat diimplementasikan dalam pendidikan Islam.

Pelaksanaan pembelajaran Bahasa Jawa berbasis pendidikan karakter dalam kurikulum 2013 seringkali memunculkan berbagai kendala yang diantaranya dapat diketahui melalui penelitian yang dilakukan oleh Vikiyono (2015) dengan judul "Implementasi Pendidikan Karakter di SDIT Qurrota A'yun Ponorogo". Hasil penelitian menunjukkan bahwa hambatan yang dialami dalam proses penanaman karakter berasal dari dalam dan dari luar. Hambatan dari dalam meliputi pendidik yang kurang bisa memahami karakteristik masing-masing siswa. Kurangnya sarana penunjang dalam kegiatan pembelajaran. Selain itu sistem full day yang ternyata memiliki beberapa kelemahan. Hambatan dari luar adalah kurangnya partisipasi aktif orang tua dalam proses penanaman karakter.

Berdasarkan beberapa penelitian diatas, dapat diketahui bahwa pendidikan karakter religius dapat diimplementasikan melalui pembelajaran Bahasa Jawa kurikulum 2013 dalam materi tembang dolanan. Hal tersebut menjadi latar belakang penulis untuk fokus mengkaji implementasi pembelajaran Bahasa Jawa (materi tembang dolanan) berbasis pendidikan karakter religius dalam kurikulum 2013.

\section{Konsep Pendidikan Karakter Religius}

Pendidikan karakter adalah proses pemberian tuntunan kepada peserta didik untuk menjadi manusia seutuhnya yang berkarakter dalam dimensi hati, pikir, raga, rasa dan karsa. Pendidikan karakter dapat dimaknai dengan pendidikan nilai, pendidikan budi pekerti, pendidikan moral, pendidikan watak, yang bertujuan untuk memberikan keputusan baik-buruk, memelihara apa yang baik, dan mewujudkan kebaikan dalam kehidupan sehari-hari dengan sepenuh hati (Wiyani, 2013: 27-28). Pendidikan karakter sebagai suatu sistem penanaman nilai-nilai karakter kepada warga sekolah yang meliputi komponen pengetahuan, kesadaran atau kemauan, dan tindakan untuk melaksanakan nilai-nilai tersebut baik terhadap Tuhan Yang Maha Esa, diri sendiri, sesama, lingkungan, maupun kebangsaan sehingga menjadi manusia insan kamil (Samani, 2013: 46).

Pendidikan karakter tidak hanya berhenti pada kawasan anak didik tahu dan paham tentang karakter-karakter mulia (kognitif), tetapi hendaknya membuat anak didik memiliki komitmen kuat pada nilai-nilai karakter itu (afektif), dan selanjutnya anak didik terdorong untuk mengaktualisasikan nilai-nilai yang 
telah menjadi milik mereka itu dalam tindak dan laku kehidupan sehari-hari (psikomotorik) (Wibowo, 2013: 18-19). Pendidikan karakter sesungguhnya bukan sekadar hubungan horizontal antara individu dan individu lain, tetapi antara individu yang memiliki hubungan vertikal dengan Allah yang diimani. Integrasi antara pendidikan agama dan pendidikan karakter di dalam lembaga pendidikan kita merupakan sebuah keharusan jika kita ingin tetap setia pada Pancasila (Majid, 2012: 63).

Secara spesifik, pendidikan karakter yang berbasis nilai religius mengacu pada nilai-nilai dasar yang terdapat dalam agama (Islam). Nilai-nilai karakter yang menjadi prinsip dasar pendidikan karakter banyak kita temukan dari beberapa sumber, diantaranya nilai-nilai yang bersumber dari keteladanan Rasulullah yang terejewantahkan dalam sikap dan perilaku sehari-harinya, yakni shiddiq (jujur), amanah (dipercaya), tabligh (menyampaikan dengan transparan), fathanah (cerdas) (Hidayatullah, 2010: 61-63). Nilai religius atau keagamaan adalah nilai yang berhubungan dengan agama, keimanan seseorang dan tanggapan seseorang terhadap nilai yang diyakini serta tindakan manusia yang memancarkan keimanan kepada Tuhan Yang Maha Esa (Jauhari, 2010:27). Nilai religius merupakan nilai yang mendasari pendidikan karakter karena pada dasarnya Indonesia adalah negara yang beragama. Nilai religius yang dijadikan sebagai salah satu pilar pendidikan karakter sangat penting ditanamkan dalam diri anak karena keyakinan seseorang terhadap kebenaran nilai yang berasal dari agama yang dipeluknya bisa menjadi motivasi kuat dalam membangun karakter (Azzet, 2011: 17-18). Pendidikan karakter bertujuan untuk membentuk setiap pribadi menjadi insan manusia yang mempunyai nilai-nilai yang utama sebagai dasar karakter yang baik sesuai dengan nilai yang berlaku di masyarakat, nilai-nilai yang utama tersebut berasal dari ajaran agama, kearifan lokal, maupun falsafah bangsa (Samsuri, 2011: 11).

Dalam pendidikan karakter religius, anak didik sengaja dibangun karakternya agar mempunyai nilai-nilai kebaikan sekaligus mempraktikkannya dalam kehidupan sehari-hari, baik itu kepada Tuhan Yang Maha Esa, dirinya sendiri, sesama manusia, lingkungan sekitar, bangsa, negara maupun hubungan internasional sebagai sesama penduduk dunia. Adapun model pelaksanaan pendidikan karakter religius dapat dilakukan melalui kegiatan pembiasaaan, keteladanan, pembinaan disiplin, CTL (contectual teaching and learning), bermain peran (role playing), dan pembelajaran partisipatif (Mulyasa, 2011:165). Pelaksanaan pendidikan karakter dalam pembelajaran dapat dilakukan ketika proses sebelum masuk ke dalam kelas, proses belajar mengajar, jam istirahat,

el Harakah Jurnal Budaya Islam Vol. 19 No.1 Tahun 2017 
pulang sekolah, kegiatan non kurikulum dan kegiatan acara. Pelaksanaan pendidikan karakter religius yang diberikan seperti guru memperkenalkan pembacaan doa kepada orangtua, doa mau belajar, doa bersyukur kepada Allah swt, pembacaan al-Asma' al-Husna, sopan santun kepada orang yang lebih tua, membaca salam ketika baru datang di sekolah, berteman dengan siapa saja, bersalaman dengan guru, dan yang lain (Atika, 2014: 747-755).

Berdasarkan pendapat beberapa ahli di atas dapat disintesiskan bahwa pendidikan karakter religius adalah proses penanaman nilai-nilai karakter religius pada diri individu dengan tujuan dapat mengaktualisasikan nilai-nilai karakter religius dalam tindakan dan perilaku di kehidupan sehari-hari.

\section{Pembelajaran Bahasa Jawa Berbasis Pendidikan Karakter}

Mengintegrasikan konten kurikulum pendidikan karakter yang telah dirumuskan ke dalam seluruh mata pelajaran wajib di SD yang relevan, terutama mata pelajaran agama, kewarganegaraan, dan bahasa (baik bahasa Indonesia maupun bahasa daerah) juga mata pelajaran muatan lokal. Muatan lokal merupakan kegiatan kurikuler untuk mengembangkan kompetensi yang disesuaikan dengan ciri khas dan potensi daerah, termasuk keunggulan daerah, yang materinya tidak dapat dikelompokkan ke dalam mata pelajaran yang ada. Substansi muatan lokal ditentukan oleh SD dan pihak SD dapat menyelenggarakan satu mata pelajaran muatan lokal setiap semester atau dua mata pelajaran muatan lokal dalam satu tahun (Wiyani, 2013: 186). Terdapat delapan belas nilai karakter yang perlu ditanamkan dalam diri peserta didik. Nilai karakter tersebut adalah religius, jujur, toleransi, disiplin, kerja keras, kreatif, mandiri, demokratis, rasa ingin tahu, semangat kebangsaan, cinta tanah air, menghargai prestasi, bersahabat, cinta damai, gemar membaca, peduli lingkungan, peduli sosial, dan tanggung jawab (Kementerian Pendidikan Nasional, 2010: 9-10). Adapun contoh Standar Isi Kurikulum 2013 Mata Pelajaran Muatan Lokal Bahasa Jawa SD/SDLB/MI Provinsi Jawa Tengah bermuatan pendidikan karakter sebagaimana dalam tabel berikut:

\begin{tabular}{ll}
\hline Kompetensi Inti & Kompetensi Dasar \\
\hline Menerima dan menjalankan ajaran & Menerima dan bangga akan anugerah Tuhan \\
agama yang dianutnya & $\begin{array}{l}\text { Yang Maha Esa berupa Bahasa Jawa sebagai } \\
\text { bahasa Ibu }\end{array}$ \\
\hline
\end{tabular}

el Harakah Jurnal Budaya Islam Vol. 19 No.1 Tahun 2017 


\begin{tabular}{|c|c|}
\hline $\begin{array}{l}\text { Memiliki perilaku jujur, disiplin, } \\
\text { tanggung jawab, santun, peduli, } \\
\text { dan percaya diri dalam berinteraksi } \\
\text { dengan keluarga, teman, dan guru }\end{array}$ & $\begin{array}{l}\text { Menunjukkan perilaku bertanggung jawab, } \\
\text { santun dan percaya diri dalam mengungkapkan } \\
\text { keinginan dan pendapat menggunakan } \\
\text { Bahasa Jawa } \\
\text { Menunjukkan perilaku berbahasa yang } \\
\text { santun yang ditunjukkan dengan ketepatan } \\
\text { penggunaan ragam bahasa (unggah-ungguh basa) } \\
\text { Menunjukkan perilaku, tindakan, dan } \\
\text { perbuatan yang mencerminkan kepribadian } \\
\text { Jawa }\end{array}$ \\
\hline $\begin{array}{l}\text { Memahami pengetahuan faktual } \\
\text { dengan cara mengamati (mendengar, } \\
\text { melihat, membaca) dan menanya } \\
\text { berdasarkan rasa ingin tahu tentang } \\
\text { dirinya, makhluk ciptaan Tuhan dan } \\
\text { kegiatannya, dan benda-benda yang } \\
\text { dijumpainya di rumah dan di sekolah }\end{array}$ & $\begin{array}{l}\text { Mengenal tokoh Pandawa dan Punakawan } \\
\text { Memahami teks pendek nonsastra tentang } \\
\text { kegiatan sehari-hari } \\
\text { Mengenal nama instrumen gamelan } \\
\text { Memahami tembang dolanan bertema disiplin }\end{array}$ \\
\hline $\begin{array}{l}\text { Menyajikan pengetahuan faktual } \\
\text { dalam bahasa yang jelas dan logis, } \\
\text { dalam karya yang estetis, dalam } \\
\text { gerakan yang mencerminkan anak } \\
\text { sehat, dan dalam tindakan yang } \\
\text { mencerminkan perilakuanak beriman } \\
\text { dan berakhlak mulia }\end{array}$ & $\begin{array}{l}\text { Mendeskripsikan tokoh Pandawa secara lisan } \\
\text { dengan ragam ngoko } \\
\text { Menceritakan kegiatan sehari-hari secara } \\
\text { lisan dengan ragam ngoko } \\
\text { Mendeskripsikan nama gamelan secara lisan } \\
\text { dan tertulis } \\
\text { Menceritakan isi tembang dolanan bertema } \\
\text { disiplin, secara lisan atau tulis }\end{array}$ \\
\hline
\end{tabular}

Tabel 1. Standar Isi Kurikulum 2013 Mata Pelajaran Muatan Lokal Bahasa Jawa

\section{Konsep Tembang Dolanan}

Kata tembang dalam Bahasa Jawa tingkatan halus (krama) disebut sekar. Sekar dalam bahasa halus juga bermakna kembang (bunga) yang sama-sama memiliki sifat yang indah dan mempesona. Sifat yang relatif sama inilah, kembang dan tembang mempunyai dasanama (sinonim) yang sama, yakni sekar (Brotosejati, 2008:8). Lelagon (tembang) dolanan adalah jenis lelagon (tembang) yang bernuansa santai, bersenang-senang, suka cita, riang gembira dan ringan tanpa beban. Kebanyakan tembang dolanan dinyanyikan oleh anak-anak yang sedang bermain (Purwadi, 2010:7).

Rahardjo (dalam Supriyadi 2010:14) lagu (tembang) dolanan adalah lagulagu yang biasa dinyanyikan anak-anak Jawa dengan gerak atau tidak. Bahkan diiringi dengan musik dan gerakan, sehingga berkesan menyenangkan. Sebagai lagu dolanan, pelaksanaannya dilakukan pada sembarang waktu dan tempat 
di mana anak-anak sering bermain dengan kelompoknya. Endraswara (dalam Supriyadi 2010:14) menjelaskan bahwa lagu (tembang) dolanan adalah lagu yang dinyanyikan dengan bermain-main atau lagu yang dinyanyikan dalam suatu permainan tertentu. Makna tembang dolanan juga disampaikan oleh Danandjaja (2007:141), yang menyatakan nyanyian rakyat (dalam hal ini tembang dolanan) adalah satu genre atau bentuk folklor lisan yang terdiri atas kata-kata dan lagu yang beredar secara lisan di antara anggota kolektif tertentu, berbentuk tradisional, serta banyak mempunyai variasi termasuk didalamnya.

Dalam masyarakat Jawa, tembang sudah ada sejak semula, bahkan sebagian besar warisan budaya nenek moyang (Jawa) dikemas dalam bentuk kidung atau tembang. Salah satu warisan budaya yang dahulu digemari oleh anak-anak (Jawa) adalah tembang dolanan. Tembang dolanan bukan hanya berfungsi sebagai lagu yang biasanya dinyanyikan oleh anak-anak ketika bermain dan bersosialisasi dengan lingkungannya, atau lagu sekedar hiburan semata-mata. Lebih dari itu tembang dolanan merupakan karya seni yang sangat menarik karena didalamnya terkandung makna yang tersirat, berisi pesan-pesan moral yang penting sebagai pembentuk karakter yang baik bagi anak bangsa. Makna yang dimaksud antara lain adalah pesan moral kepada anak-anak untuk memiliki sikap dan kepribadian yang religius.

Tembang dolanan merupakan salah satu sarana komunikasi dan sosialisasi anak-anak dengan lingkungannya. Melalui tembang dolanan, anak-anak dapat bergembira, bermain dan bersenang-senang ketika mengisi waktu luang. Tembang dolanan merupakan suatu hal yang menarik bagi anak. Meskipun sarat dengan pesan moral yang mendidik, tembang dolanan disampaikan dalam bahasa yang sederhana sehingga mudah dihafal dan dicerna sesuai dengan tingkat kematangan psikologis atau perkembangan jiwa anak yang masih suka bermain. Pesan atau ajaran-ajaran dan nilai-nilai religius serta nilai moral budi pekerti dalam tembang dolanan disampaikan melalui perumpamaanperumpamaan dan analogi yang dikemas dalam bahasa yang sederhana namun tetap indah (estetis).

Dalam penelitian yang dilakukan oleh Nugrahani (2012) yang berjudul "Reaktualisasi Tembang Dolanan Jawa dalam Rangka Pembentukan Karakter Bangsa (Kajian Semiotik)" dijelaskan bahwa melalui pembelajaran Bahasa Jawa dengan materi tembang dolanan Jawa diharapkan usaha pelestarian budaya tradisional Jawa dapat berlangsung dengan baik. Melalui bimbingan gurunya dalam pembelajaran Bahasa Jawa anak-anak dapat mengapresiasi tembang dolanan Jawa yang sarat akan nilai-nilai luhur sebagai pembentuk 
karakternya. Dengan demikian, diharapkan bahwa melalui pembelajaran yang dilaksanakan anak-anak dapat tumbuh menjadi manusia yang berbudaya, mandiri, mampu mengaktualisasikan diri dengan potensinya, mengekspresikan pikiran dan perasaannya, memiliki wawasan yang luas, mampu berpikir kritis, dan berkarakter kuat, sehingga peka terhadap masalah sosial pada bangsanya.

Dari beberapa pendapat di atas dapat disimpulkan bahwa tembang dolanan adalah suatu jenis lagu (tembang) yang biasanya dinyanyikan oleh anak-anak saat bermain (dolanan), bisa dengan atau tanpa iringan musik. Biasanya tembang dolanan berirama senang, semangat, dan gembira sesuai dengan karakter anak.

\section{Konsep Kurikulum 2013}

Dalam Permendikbud Nomor 81a Tahun 2013 dijelaskan bahwa pengembangan kurikulum merupakan kegiatan sistematis dan terencana yang terdiri atas kegiatan pengembangan ide kurikulum, dokumen kurikulum, implementasi kurikulum, dan evaluasi kurikulum. Keempat dimensi pengembangan kurikulum ini saling terkait dan merupakan satu kesatuan keseluruhan proses pengembangan (lamp. V, hlm: 1). Adapun pengembangan kurikulum dalam dunia pendidikan melahirkan sebuah kurikulum baru yang dinamakan kurikulum 2013. Kurikulum 2013 adalah sebuah kurikulum yang dikembangkan untuk meningkatkan dan menyeimbangkan kemampuan soft skills dan hard skills yang berupa sikap, keterampilan, dan pengetahuan (Fadlillah, 2014: 16). Dalam kurikulum 2013 terdapat pendekatan yang digunakan dalam proses pembelajaran, yaitu pendekatan scientific dan tematik integratif. Pendekatan scientific adalah pendekatan yang digunakan dalam pembelajaran melalui proses ilmiah. Pembelajaran dengan pendekatan saintifik adalah proses pembelajaran yang dirancang sedemikian rupa agar peserta didik secara aktif mengkonstruksi konsep, hukum atau prinsip melalui tahapan-tahapan mengamati (untuk mengidentifikasi atau menemukan masalah), merumuskan masalah, mengajukan atau merumuskan hipotesis, mengumpulkan data dengan berbagai teknik, menganalisis data, menarik kesimpulan dan mengomunikasikan konsep, hukum atau prinsip yang "ditemukan" (Daryanto, 2014: 51).

Istilah Standar Kompetensi (SK) dalam kurikulum KTSP, kini berubah menjadi Kompetensi Inti (KI) dalam kurikulum 2013. Adapun rumusan Kompetensi Inti dalam kurikulum 2013 adalah KI-1 untuk kompetensi inti sikap spiritual, KI-2 untuk kompetensi inti sikap sosial, KI-3 untuk kompetensi inti pengetahuan, dan KI-4 untuk kompetensi inti keterampilan. Untuk

el Harakah Jurnal Budaya Islam Vol. 19 No.1 Tahun 2017 
mendukung kompetensi inti ini, capaian pembelajaran mata pelajaran dapat diuraikan menjadi kompetensi-kompetensi dasar (Prastowo, 2013: 219).

Dalam Permendikbud Nomor 20 Tahun 2016 tentang Standar Kompetensi Lulusan Pendidikan Dasar dan Menengah menjelaskan bahwa Standar Kompetensi Lulusan adalah kriteria mengenai kualifikasi kemampuan lulusan yang mencakup sikap, pengetahuan, dan keterampilan. Standar Kompetensi Lulusan digunakan sebagai acuan utama pengembangan standar isi, standar proses, standar penilaian pendidikan, standar pendidik dan tenaga kependidikan, standar sarana dan prasarana, standar pengelolaan, dan standar pembiayaan. Setiap lulusan satuan pendidikan dasar dan menengah memiliki kompetensi pada tiga dimensi yaitu sikap, pengetahuan, dan keterampilan. Kompetensi dimensi sikap, pengetahuan, dan keterampilan pada jenjang SD/MI/SDLB/ Paket A adalah sebagaimana dalam tabel berikut:

\begin{tabular}{|c|c|c|}
\hline Dimensi Sikap & Dimensi Pengetahuan & Dimensi Keterampilan \\
\hline $\begin{array}{l}\text { Memiliki perilaku yang } \\
\text { mencerminkan sikap: } \\
\text { 1. Beriman dan } \\
\text { bertakwa kepada } \\
\text { Tuhan YME, } \\
\text { 2. Berkarakter, jujur, } \\
\text { dan peduli, } \\
\text { 3. Bertanggungjawab, } \\
\text { 4. Pembelajar sejati } \\
\text { sepanjang hayat, dan } \\
\text { 5. Sehat jasmani dan } \\
\text { rohani sesuai dengan } \\
\text { perkembangan } \\
\text { anak di lingkungan } \\
\text { keluarga, sekolah, } \\
\text { masyarakat dan } \\
\text { lingkungan alam } \\
\text { sekitar, bangsa, dan } \\
\text { negara. }\end{array}$ & $\begin{array}{l}\text { Memiliki pengetahuan } \\
\text { faktual, konseptual, } \\
\text { prosedural, dan } \\
\text { metakognitif pada tingkat } \\
\text { dasar berkenaan dengan: } \\
\text { 1. Ilmu pengetahuan, } \\
\text { 2. Teknologi, } \\
\text { 3. Seni, dan } \\
\text { 4. Budaya. } \\
\text { 5. Mampu mengaitkan } \\
\text { pengetahuan di atas } \\
\text { dalam konteks diri } \\
\text { sendiri, keluarga, } \\
\text { sekolah, masyarakat } \\
\text { dan lingkungan alam } \\
\text { sekitar, bangsa, dan } \\
\text { negara. }\end{array}$ & $\begin{array}{l}\text { Memiliki keterampilan } \\
\text { berpikir dan bertindak: } \\
\text { 1. Kreatif, } \\
\text { 2. Produktif, } \\
\text { 3. Kritis, } \\
\text { 4. Mandiri, } \\
\text { 5. Kolaboratif, dan } \\
\text { 6. Komunikatif } \\
\text { Melalui pendekatan } \\
\text { ilmiah sesuai dengan } \\
\text { tahap perkembangan } \\
\text { anak yang relevan } \\
\text { dengan tugas yang } \\
\text { diberikan. }\end{array}$ \\
\hline
\end{tabular}

Tabel 2. Kompetensi dimensi sikap, pengetahuan, dan keterampilan pada jenjang SD/ MI/SDLB/ Paket A

Sementara itu dalam Permendikbud Nomor 21 Tahun 2016 Tentang Standar Isi Pendidikan Dasar dan Menengah menjelaskan tentang Kompetensi Inti sebagaimana dalam tabel berikut: 


\begin{tabular}{ll}
\hline Kompetensi Inti & Deskripsi Kompetensi \\
\hline Sikap Spiritual & $\begin{array}{l}\text { Menerima, menjalankan, dan menghargai ajaran agama yang } \\
\text { dianutnya. }\end{array}$ \\
\hline Sikap Sosial & $\begin{array}{l}\text { Menunjukkan perilaku: a) jujur; b) disiplin; c) santun; d) percaya } \\
\text { diri; e) peduli, dan f) bertanggung jawab dalam berinteraksi } \\
\text { dengan keluarga, teman, guru, dan tetangga, dan negara. }\end{array}$ \\
\hline Pengetahuan & $\begin{array}{l}\text { Memahami pengetahuan faktual, konseptual, prosedural, dan } \\
\text { metakognitif pada tingkat dasar dengan cara: a) mengamati; }\end{array}$ \\
& $\begin{array}{l}\text { b) menanya; c) mencoba } \\
\text { Berdasarkan rasa ingin tahu tentang dirinya, makhluk ciptaan } \\
\text { Tuhan dan kegiatannya, dan benda-benda yang dijumpainya } \\
\text { di rumah, di sekolah, dan tempat bermain. }\end{array}$ \\
\hline Keterampilan & $\begin{array}{l}\text { Menunjukkan keterampilan berfikir dan bertindak: a) kreatif; b) } \\
\text { produktif; c) kritis; d) mandiri; e) kolaboratif, dan f) komunikatif } \\
\text { Dalam bahasa yang jelas, sistematis, logis dan kritis, dalam } \\
\text { karya yang estetis, dalam gerakan yang mencerminkan anak } \\
\text { sehat, dan tindakan yang mencerminkan perilaku anak sesuai } \\
\text { dengan tahap perkembangannya. }\end{array}$
\end{tabular}

Tabel 3. Kompetensi Inti Permendikbud Nomor 21 Tahun 2016

Berdasarkan pendapat beberapa ahli di atas dapat disintesiskan bahwa kurikulum 2013 adalah kurikulum berbasis pendekatan saintifik yang dikembangkan untuk menyempurnakan kurikulum sebelumnya dengan tujuan untuk meningkatkan dan menyeimbangkan kemampuan soft skills dan hard skills yang berupa sikap, keterampilan, dan pengetahuan.

\section{Metode Penelitian}

Jenis penelitian ini adalah penelitian kualitatif dengan pendekatan studi kasus tunggal. Penelitian kualitatif adalah penelitian yang bermaksud untuk memahami fenomena tentang apa yang dialami oleh subjek penelitian misalnya perilaku, persepsi, motivasi, tindakan, dll secara holistik dan dengan cara deskripsi dalam bentuk kata-kata dan bahasa pada suatu konteks khusus yang alamiah dan dengan memanfaatkan berbagai metode alamiah (Moleong, 2010: 6). Studi kasus adalah uraian dan penjelasan komprehensif mengenai berbagai aspek seorang individu, suatu kelompok, suatu organisasi (komunitas), suatu program, atau suatu situasi sosial (Mulyana, 2007: 201). Penelitian ini menggunakan kasus tunggal karena penelitiannya hanya dilakukan pada satu sasaran (satu lokasi atau satu objek), sehingga strategi penelitian yang 
relevan adalah studi kasus (Case Study). Peneliti studi kasus berupaya menelaah sebanyak mungkin data mengenai subjek yang diteliti. Dengan mempelajari semaksimal mungkin seorang individu, suatu kelompok, atau suatu kejadian, peneliti bertujuan memberikan pandangan yang lengkap dan mendalam mengenai subjek yang diteliti.

\section{Hasil Penelitian}

\section{Analisis Nilai Religius dalam Lirik Tembang Dolanan}

\section{Sluku-Sluku Bathok}

Sluku-sluku bathok

Bathoke ela-elo

Si Rama menyang Solo

Oleh-olehe payung motha

Mak jenthit lolo lobah

Wong mati ora obah

Nek obah medeni bocah

Nek urip goleka dhuwit

Lirik tembang dolanan yang berjudul 'Sluku-Sluku Bathok' tersebut apabila diterjemahkan ke dalam bahasa Indonesia sebagai berikut.

Ayun-ayun kepala

Kepalanya geleng-geleng

Si bapak pergi ke Solo

Oleh-olehnya payung mutha

Secara tiba-tiba bergerak

Orang mati tidak bergerak

Kalau bergerak menakuti orang

Kalau hidup carilah uang

Dalam penelitian yang dilakukan oleh Inayati dan Ahmad (2016) yang berjudul "Islamic Education and Multiple Intelligences Implementation in Traditional Game of Sluku-Sluku Bathok at Komunitas Pojok Budaya, Bantul of Yogyakarta" dikemukakan bahwa lirik sluku-sluku bathok disusun oleh Sunan Kalijaga, yang ditulis sebagai media untuk menyampaikan ajaran Islam. Slukusluku bathok adalah kata-kata Jawa yang berarti mlaku-mlaku nganggo pathokan (berjalan-jalan menggunakan pedoman). Bathok adalah cangkoking krambil atau tempurung kelapa. Sluku-sluku bathok berarti berjalan dengan bimbingan, ketika berkorelasi dengan tempurung kelapa, yang berarti bahwa orang harus 
mengambil bimbingan yang kuat dan solid sehingga mereka akan hidup bahagia baik di dunia dan akhirat. Kata ela elo diambil dari bahasa Arab la ilaha illallah yang artinya tidak ada Tuhan selain Allah. Dalam hal ini, kata ela elo menjelaskan kalimat pertama (sluku-sluku bathok). Jadi, pedoman bagi manusia dalam kehidupan mereka di dunia dan akhirat adalah dengan bersaksi bahwa tidak ada Tuhan selain Allah.

Kemudian baris ketiga adalah si Rama menyang Solo, itu berasal dari frase siramo kanthi shalat. Siramo terbentuk dari si+Rama, sedangkan kata kanthi adalah identik dengan kata menyang, dan Solo terbentuk dari shalat, yang berarti untuk membersihkan tubuh (wudlu/ mengambil wudhu) dan kemudian melakukan shalat. Ketika itu diurutkan dari baris pertama, penjelasan dari sluku-sluku bathok adalah jika seseorang telah bersaksi dengan menyatakan la ilaha illallah (ela elo), yang harus dilakukan sebagai tindak lanjut adalah membersihkan tubuh dan kemudian melakukan shalat. Baris berikutnya adalah oleh-olehe payung mutha. Arti dari kalimat ini adalah ketika bersaksi pada Allah dan kemudian dilakukan shalat, ia akan mendapatkan perlindungan dari Allah. Payung adalah simbol perlindungan, sementara mutha adalah sesuatu yang terbuat dari kulit. Biasanya, tidak ada payung terbuat dari kulit, sehingga, payung mutha adalah simbol perlindungan besar dari Allah.

Lirik berikutnya adalah mak jenthit lolo lobah. Dalam kamus Jawa, mak berarti mertelakake tumindak atau sesuatu yang menyebabkan orang untuk melakukan tindakan. Di sisi lain, jenthit berarti melakukan tindakan dengan cepat. Jadi, mak jenthit lolo lobah terkandung pesan bahwa seseorang harus menyatakan/ bersaksi dan percaya bahwa tidak ada Tuhan selain Allah dan diikuti dengan menyembah Allah. Lirik berikutnya wong mati ora obah, nek obah medeni bocah, berarti orang mati tidak bisa bergerak, jika bisa bergerak akan menakuti anak-anak. Lirik ini datang sebagai alasan dari lirik sebelumnya; mengapa kita harus menyaksikan Allah dalam doa dan perilaku ketika mereka masih hidup? karena wong mati ora obah, jika orang sudah mati maka tidak akan mampu melakukan apa-apa bahkan untuk menyaksikan Allah. Kemudian, nek obah medeni bocah bermakna bahwa meskipun Allah memiliki kekuatan untuk menghidupkan orang yang sudah mati sehingga ia bisa membaca syahadat, tapi Allah tidak akan pernah melakukannya karena meramaikan orang mati akan membawa lebih banyak mudharat (kelemahan) daripada mashlahah (manfaat).

Dalam lirik terakhir menyatakan, nek urip goleke duit. Dalam bahasa Indonesia, artinya jika orang mati hidup, lebih baik ia mencari uang. Makna tersirat dari lirik ini adalah bahwa kesempatan berbuat baik adalah ketika orang 
masih hidup. Selain itu, juga menyiratkan makna dalam lirik sebelumnya nek mati ora obah, yaitu orang mati tidak bisa melakukan apa-apa bahkan untuk bergerak, sehingga ia tidak memiliki kesempatan untuk berbuat baik lagi

Jadi dapat disimpulkan bahwa dalam tembang dolanan 'Sluku-Sluku Bathok' tersebut mengandung banyak nilai religius. Dalam syair tersebut mengandung makna bahwa manusia hendaklah membersihkan batinnya dan senantiasa berzikir mengingat Allah dengan (ela-elo) menggelengkan kepala mengucapkan lafal laa illa ha illallah disaat senang maupun susah, di kala menerima musibah maupun kenikmatan. Hidup mati manusia hanyalah di tangan Allah, maka dari itu selagi masih diberikan hidup kita wajib berbuat baik terhadap sesama dan senantiasa beribadah kepada Allah swt. Sebagai manusia wajib bertawakal atas segala kehendak yang telah ditentukan oleh Allah swt. baik dalam urusan rejeki, jodoh dan maut.

Pada tembang dolanan Sluku-sluku Bathok terdapat nilai-nilai moral dan budi pekerti luhur yang perlu diinternalisasikan dalam pendidikan. Di antaranya adalah 1) kita harus selalu membersihkan hati kita dengan cara selalu berdzikir, 2) mengakui tidak ada Tuhan selain Allah, 3) mengikuti ajaran Rasulullah saw, 4) tiada kekuatan selain dari Allah dan selalu berharap khusnul khotimah, 5) selalu mengedepankan introspeksi/mawas diri, 6) mencintai Allah, selalu berbuat baik, dan bertaubat, 7) kita akan mulia di sisi Allah karena takwa kita dan memahami asal-usul kita (ngerti sangkan paraning dumadi).

\section{Ilir-ilir}

Lir-ilir, llir-ilir, tandure wis sumilir

Tak ijo royo-royo, tak sengguh temanten anyar

Cah angon, cah angon penekna blimbing kuwi

Lunyu-lunyu penekna kanggo mbasuh dodotira

Dodotira-dodotira kumitir bedhah ing pinggir

Dondomana, jlumantana, kanggo seba mengko sore

Mumpung gedhe rembulane, mumpung jembar kalangane

Ya suraka surak hore

Lirik tembang dolanan yang berjudul 'Ilir-Ilir' tersebut apabila diterjemahkan ke dalam bahasa Indonesia sebagai berikut:

Bangunlah, bangunlah, tanaman sudah bersemi

Warnanya menghijau, ibarat pengantin baru

Anak gembala, anak gembala, panjatkan belimbing itu

Walaupun licin tetap panjatlah untuk mencuci kainmu

Pakaianmu, pakaianmu terkoyak bagian samping 
Jahitlah dan benahilah untuk menghadap Gustimu nanti sore Selagi rembulan masih purnama, selagi tempat masih luas dan lapang Ayo bersorak, bersorak hore

Dalam lirik tembang dolanan yang berjudul 'Ilir-ilir' mengandung makna religius (keagamaan). Adapun maksud yang terkandung dalam tembang tersebut adalah bahwa kita sebagai umat manusia diminta bangun dari keterpurukan untuk lebih mempertebal iman dan berjuang untuk mendapatkan kebahagiaan seperti bahagianya sepasang pengantin baru. Selanjutnya terdapat lirik yang meminta si anak gembala untuk memetikkan buah belimbing yang diibaratkan perintah shalat lima waktu. Perintah wajib ini harus dilaksanakan dengan sungguh-sungguh dan selalu berusaha untuk menjalankan rukun Islam apapun halangan dan resikonya. Meskipun ibarat pakaian kita terkoyak lubang sana sini, namun kita sebagai umat diharapkan untuk selalu memperbaiki dan mempertebal iman serta taqwa agar kita siap memenuhi panggilan Allah swt.

Tembang Ilir-ilir adalah karya dari Sunan Ampel, yang merupakan salah satu dari Walisanga. Di dalam tembang tersebut mengandung banyak nilai positif, antara lain nilai etos kerja atau karakter kuat yang tergambar pada lirik cah angon penekna blimbing kuwi, lunyu-lunyu penekna kanggo masuh dodotira (penggembala panjatkan pohon belimbing itu, meskipun sangat licin panjatlah untuk membersihkan pakaian). Dari lirik tersebut dapat dipetik pelajaran bahwa untuk mewujudkan keinginan baik (cita-cita) yakni mendapatkan blimbing harus disertai dengan upaya yang sungguh-sungguh dan berikhtiar sekuat tenaga. Lirik tersebut menggambarkan perjuangan ketika memanjat pohon yang sangat licin pasti akan banyak menemui hambatan dan rintangan. Blimbing yang selalu bergigir lima dalam dapat dimaknai sebagai lima sila Pancasila sebagai dasar negara Republik Indonesia. Dasar negara ini harus selalu dipertahankan karena sebagai pemersatu bangsa Indonesia, dan hal ini tentu membutuhkan perjuangan serta tekad yang luar biasa.

Tembang Ilir-ilir merupakan satu contoh tembang yang mengajarkan kehidupan beragama, terutama Islam. Konon, tembang ini dinyanyikan dan disusun oleh Sunan Kalijaga yang bertujuan mengingatkan orang Islam untuk selalu menjalankan rukun Islam dan salat lima waktu. Ada pendapat lain yang menyatakan bahwa tembang dolanan ini dari masa Kanjeng Sunan Giri di Gresik, pada periode "Kebudayaan Jawa Pesisiran (zaman Islam)". Zaman Islam pada periode antara Sastra Jawa Tengahan dan Zaman Surakarta Awal. Jadi tembang dolanan ini berhubungan dengan ajaran agama Islam, yakni anjuran bahwa senyampang masih sehat wal afiat, waktu longgar, alam terang benderang,

el Harakah Jurnal Budaya Islam Vol. 19 No.1 Tahun 2017 
tiada halangan apa pun, hendaknya seba (menghadap/bersembah) pada "Raja" (Lord, Tuhan Allah), dengan berpakaian bersih, rapi (tidak robek), meskipun tidak harus baru, dan dengan upaya sungguh-sungguh, bukan terpaksa.

Pengetahuan dan pengalaman menghayati tembang dolanan yang ternyata berisi pesan tersamar ini memunculkan pendapat bahwa seni tidak hanya indah saja, tetapi juga baik dan benar, bermakna; tidak hanya sekadar pertunjukan (show) makna ekstrinsik, tetapi juga sebagai petunjuk, ajaran moral, makna intrinsik. Kanjeng sunan mengingatkan agar orang-orang Islam segera bangun dan bergerak karena saatnya telah tiba. Bagaikan tanaman yang telah siap dipanen, demikian pula rakyat di Jawa saat itu (setelah kejatuhan Majapahit) telah siap menerima petunjuk dan ajaran Islam dari para wali. Hijau adalah warna kejayaan Islam, dan agama Islam disini digambarkan seperti pengantin baru yang menarik hati siapapun yang melihatnya dan membawa kebahagiaan bagi orang-orang sekitarnya. Adapun yang disebut anak gembala disini adalah para pemimpin sedangkan belimbing adalah buah bersegi lima, yang merupakan simbol dari lima rukun Islam dan salat lima waktu.

Jadi para pemimpin diperintahkan oleh Sunan Kalijaga untuk memberi contoh kepada rakyatnya dengan menjalankan ajaran Islam secara benar yaitu dengan menjalankan lima rukun Islam dan salat lima waktu. Dodot adalah sejenis kain kebesaran orang Jawa yang hanya digunakan pada upacara-upacara atau saat-saat penting. Adapun buah belimbing pada jaman dahulu, karena kandungan asamnya sering digunakan sebagai pencuci kain, terutama untuk merawat kain batik supaya tetap awet. Dengan kalimat ini Sunan Kalijaga memerintahkan orang Islam untuk tetap berusaha menjalankan lima rukun Islam dan salat lima waktu walaupun banyak rintangannya (licin jalannya). Semuanya itu diperlukan untuk menjaga kehidupan beragama mereka. Karena menurut orang Jawa, agama itu seperti pakaian bagi jiwanya. Walaupun bukan sembarang pakaian biasa. Saat itu kemerosotan moral telah menyebabkan banyak orang meninggalkan ajaran agama mereka sehingga kehidupan beragama mereka digambarkan seperti pakaian yang telah rusak dan robek.

'Seba' artinya menghadap orang yang berkuasa (raja/gusti), oleh karena itu disebut 'paseban' yaitu tempat menghadap raja. Di sini Sunan Kalijaga memerintahkan agar orang Jawa memperbaiki kehidupan beragamanya yang telah rusak dengan cara menjalankan ajaran agama Islam secara benar, untuk bekal menghadap Allah swt. di hari nanti. Selagi masih banyak waktu, selagi masih lapang kesempatan, perbaikilah kehidupan beragamamu. Pada saatnya nanti akan datang panggilan dari Yang Maha Kuasa, sepatutnya bagi mereka 
yang telah menjaga kehidupan beragamanya dengan baik untuk menjawabnya dengan gembira.

\section{Padhang Bulan}

Yo prakanca dolanan ing njaba

Padhang bulan padhangé kaya rina

Rembulané kang ngawé-awé

Ngélingaké aja turu soré-soré

Lirik tembang dolanan yang berjudul 'Padhang Bulan' tersebut apabila diterjemahkan ke dalam bahasa Indonesia sebagai berikut.

Ayo teman-teman bermain diluar

Cahaya bulan yang terang benderang

Rembulan yang seakan-akan melambaikan tangan

Mengingatkan kepada kita untuk tidak tidur sore-sore

Dalam tembang dolanan Padhang Bulan mengandung makna religius (keagamaan). Makna yang terkandung dalam tembang dolanan tersebut adalah mengingatkan kita agar selalu bersyukur kepada yang Maha Kuasa atas kenikmatan dari keindahan alam. Untuk menunjukkan rasa syukur tersebut kita diharapkan tidak tidur terlalu sore karena kita bisa melaksanakan lebih banyak ibadah di waktu malam, seperti salat sunnah, membaca Al-Quran, berdzikir, dan sebagainya. Malam hari merupakan waktu yang tepat untuk melakukan ibadah lebih banyak, setelah pada pagi hingga sore hari orangorang telah sibuk bekerja dan melakukan aktivitas yang lainnya.

Tembang dolanan Padhang Bulan ini selain berisi ajakan untuk bermain bersama juga bertujuan untuk menciptakan suasana yang selaras, seimbang, dan serasi dalam kehidupan bermasyarakat anak-anak. Di samping itu, tembang dolanan ini mampu menunjukkan kekompakan, keakraban, kebersamaan, solidaritas, senasib seperjuangan, tenggang rasa, dan membina kerukunan, persahabatan, dan persaudaraan. Larik ngélingaké aja turu soré-soré 'mengingatkan agar tidak tidur sore' mengandung nilai kepercayaan yang dianut oleh masyarakat (Jawa), yaitu telek dibuntel klaras 'kotoran dibungkus daun pisang kering' artinya betah melek seger waras 'kuat menahan kantuk akan sehat'. Makna yang terkandung dalam ungkapan tersebut adalah kita tidak selalu bisa menikmati terang bulan, suasana yang indah dan mengasyikan untuk berkumpul, bercanda ria, bermain, berbagi cerita dan sebagainya. Dengan betah melek kita akan terhindar dari penyakit dan mudah memperoleh rejeki dalam bentuknya yang beragam.

el Harakah Jurnal Budaya Islam Vol. 19 No.1 Tahun 2017 


\section{Implementasi Pembelajaran Bahasa Jawa (Materi Tembang Dolanan) Berbasis Pendidikan Karakter Religius dalam Kurikulum 2013}

Berdasarkan analisis nilai religius dalam lirik tembang dolanan di atas, maka dapat diketahui bahwa ketiga tembang dolanan tersebut sangat kaya akan nilainilai religius yang mampu berperan sebagai media pendidikan karakter. Bentuk implementasi pendidikan karakter berbasis nilai religius ini dapat tersampaikan secara baik melalui lirik-lirik tembang dolanan. Melalui media ini pesan yang bernilai religius tentu akan lebih mudah tersampaikan khususnya bagi anakanak. Pendidikan karakter tidak hanya diperoleh melalui proses pembelajaran di dalam kelas saja, tetapi juga bisa diperoleh di luar kelas, misalnya dengan cara pembelajaran di luar kelas berbasis permainan. Pembelajaran seperti ini tentu sangat menyenangkan bagi anak karena mereka akan memperoleh ilmu tanpa harus menghafal ataupun berhitung. Maka disinilah peran guru sangat dibutuhkan untuk mengajak anak belajar sambil bermain dengan menyanyikan tembang-tembang dolanan. Guru dapat menyampaikan arti dan makna yang terkandung pada setiap lirik tembang dolanan tersebut dengan tetap sambil bermain dan suasana santai yang menyenangkan. Berikut ini adalah model pembelajaran yang dapat digunakan.

\section{Model Pembelajaran Role Playing}

Role Playing (bermain peran) sebagai suatu model pembelajaran bertujuan untuk membantu siswa menemukan diri (jati diri) didunia sosial dan memecahkan dilema dengan bantuan kelompok (Uno, 2009: 26). Dalam model role playing ini beberapa siswa memainkan peran atau tokoh seperti pada soal yang diberikan, kemudian siswa yang lain mengidentifikasi informasi yang diberikan dari soal tersebut seperti apa yang diketahui dan apa yang ditanyakan. Setelah itu siswa mendiskusikan soal tersebut beserta penyelesaiannya, kemudian salah satu siswa menuliskan jawaban yang diperoleh di papan tulis dan dibahas bersama-sama. Dengan menggunakan model bermain peran diharapkan kemampuan pemahaman dapat dimiliki siswa. Karena dengan model bermain peran dapat mengarahkan siswa lebih merasakan secara langsung berproses nyata seperti dalam kehidupan seharihari. Dalam hal ini, guru berperan sebagai fasilitator. Keberhasilan model pembelajaran melalui bermain peran tergantung pada kualitas permainan peran (enactment) yang diikuti dengan analisis terhadapnya. Di samping itu, tergantung pula pada persepsi siswa tentang peran yang dimainkan terhadap situasi yang nyata (real life situation). 
Belajar dengan cara bermain dan bernyanyi seperti itu akan lebih mudah untuk menyampaikan makna dan pesan dalam sebuah tembang dolanan pada anak. Mereka tidak harus menghafalkan tetapi akan secara otomatis terekam dalam ingatan mereka karena dilakukan dengan cara bernyanyi bersama-sama. Anak yang semula kurang hafal dengan lirik tembang dolanan tersebut akan menjadi hafal karena dinyanyikan langsung bersama dengan teman-temannya, sedangkan bagi anak yang belum memahami arti dan makna dalam lirik tembang dolanan tersebut akan menjadi paham karena dijelaskan oleh guru dengan cara yang menyenangkan pula. Langkah awal dalam proses belajar dengan menggunakan tembang dolanan adalah dengan mengenalkannya lalu menciptakan rasa senang, cinta, dan bangga ketika menyanyikan tembang dolanan tersebut. Ketika anak sudah mulai senang menyanyikan tembang dolanan, maka pasti akan muncul rasa penasaran dengan arti dan makna pada lirik-lirik tembang dolanan yang telah mereka senandungkan tersebut.

Setelah anak mampu memahami arti dan makna pada setiap lirik tembang dolanan, maka akan lebih mudah mengajak mereka untuk mengimplementasikan nilai-nilai tersebut dalam kehidupan sehari-hari yang dapat dimulai dengan hal-hal kecil dari lingkungan sekitar mereka. Inilah yang disebut dengan pendidikan karakter berbasis nilai religius dalam tembang dolanan. Misalnya dalam tembang dolanan 'Sluku-Sluku Bathok' mengandung makna bahwa manusia hendaklah membersihkan batinnya dan senantiasa berzikir mengingat Allah dengan (ela-elo) menggelengkan kepala mengucapkan lafal laa illa ha illallah disaat senang maupun susah. Dari sini kita dapat mengajak anak untuk bersamasama membaca lafal laa illa ha illallah dan menjelaskan arti dari lafal tersebut yaitu tidak ada Tuhan selain Allah. Pada tembang dolanan Sluku-sluku Bathok terdapat nilai-nilai moral dan budi pekerti luhur yang perlu diinternalisasikan dalam pendidikan dengan cara mengajak mereka berdzikir bersama-sama, menjelaskan ajaran-ajaran Rasulullah saw, dan sebagainya.

Berdasarkan uraian di atas, dapat disimpulkan bahwa model pembelajaran Role Playing dapat dilakukan dengan cara mengajak salah satu siswa untuk bermain peran sebagai seorang imam dalam salat berjamaah. Sementara itu siswa yang lain memperhatikan dan guru berperan sebagai fasilitator. Guru memberikan umpan berupa tebakan bacaan pada beberapa gerakan salat, misalnya ketika tahiyat awal yang didalamnya terdapat bacaan laa illa ha illallah yang relevan dengan salah satu syair tembang dolanan Sluku-sluku Bathok, kemudian guru memberikan penguatan.

el Harakah Jurnal Budaya Islam Vol. 19 No.1 Tahun 2017 


\section{Model Pembelajaran Discovery Learning}

Discovery Learning adalah model pembelajaran untuk menemukan sesuatu yang bermakna dalam pembelajaran yang dilakukan dengan prosedur pemberian stimulus, identifikasi masalah, pengumpulan data, pengolahan data, verifikasi, dan generalisasi (Permendikbud Nomor 65 Tahun 2013). Model pembelajaran penemuan (discovery learning) adalah pembelajaran yang materi pembelajarannya tidak disajikan dalam bentuk final, tetapi siswa dihadapkan pada suatu permasalahan yang direkayasa oleh guru. Siswa diminta untuk mengerahkan segala kemampuannya agar permasalahan tersebut dapat terpecahkan melalui kegiatan pengamatan, menggolongkan, membuat dugaan, menjelaskan, menarik kesimpulan. Kegiatan tersebut dapat membimbing siswa untuk menemukan konsep dan prinsip-prinsip melalui proses penemuan sendiri.

Dalam lirik tembang dolanan yang berjudul 'Ilir-ilir' juga mengandung banyak makna religius (keagamaan). Terdapat lirik yang meminta si anak gembala untuk memetikkan buah belimbing yang diibaratkan perintah shalat lima waktu. Di sini kita bisa mengajak anak untuk membaca niat salat fardhu secara bersama-sama atau bahkan praktik salat berjamaah. Blimbing yang selalu bergigir lima dapat dimaknai sebagai lima sila Pancasila sebagai dasar negara Republik Indonesia. Dasar negara ini harus selalu dipertahankan karena sebagai pemersatu bangsa Indonesia. Dari sini kita bisa mengajak anak untuk menyebutkan satu persatu dari lima butir sila Pancasila secara bersama-sama. Simbol buah belimbing juga dapat dimaknai sebagai rukun Islam yang juga berjumlah lima. Disinilah siswa bisa kita ajak untuk menyebutkan rukun Islam, dan mengingatkan untuk tidak dihafalkan saja tetapi juga harus selalu dilaksanakan. Jadi tembang dolanan ini berhubungan dengan ajaran agama Islam, yakni anjuran bahwa senyampang masih sehat wal afiat, waktu longgar, alam terang benderang, tiada halangan apa pun, hendaknya seba (menghadap/ bersembah) pada "Raja" (Lord, Tuhan Allah), dengan berpakaian bersih, rapi (tidak robek), meskipun tidak harus baru, dan dengan upaya sungguhsungguh, bukan terpaksa. Hal ini mengingatkan pada anak bahwa sebelum menjalankan ibadah salat, maka diwajibkan untuk bersuci terlebih dahulu dengan cara mengambil wudhu dan menggunakan pakaian yang bersih, rapi, dan sopan tetapi tidak harus pakaian baru.

Berdasarkan uraian di atas, dapat disimpulkan bahwa model pembelajaran Discovery Learning dapat dilakukan dengan cara pemberian sebuah permasalahan dari guru kepada siswa yang membutuhkan sebuah pemecahan. Misalnya 
guru menyanyikan tembang dolanan Ilir-ilir di awal pembelajaran, kemudian guru mengajak siswa untuk menemukan objek-objek yang menarik dalam syair tembang dolanan Ilir-ilir tersebut. Dalam kegiatan mengamati lirik tembang dolanan Ilir-ilir tersebut, siswa pasti melakukan pengumpulan dan pengolahan data. Setelah siswa menemukan simbol-simbol dalam tembang dolanan Ilir-ilir tersebut, siswa akan membuat dugaan mengenai makna dari simbol-simbol tersebut. Kemudian guru memberikan umpan agar siswa berani menjelaskan simbol-simbol tersebut sesuai kemampuan mereka. Selanjutnya guru memberikan apresiasi, klarifikasi, dan pengenalan pendidikan karakter religius dalam tembang dolanan Ilir-ilir.

\section{Model Pembelajaran Problem Based Learning}

Problem Based Learning adalah model pembelajaran yang bertujuan merangsang peserta didik untuk belajar melalui berbagai permasalahan nyata dalam kehidupan sehari-hari, dihubungkan dengan pengetahuan yang dipelajarinya. Problem Based Learning dapat dilakukan dengan prosedur mengorientasi peserta didik pada masalah, mengorganisasikan kegiatan pembelajaran, membimbing penyelidikan mandiri dan kelompok, mengembangkan dan menyajikan hasil karya, analisis dan evaluasi proses pemecahan masalah (Permendikbud Nomor 65 Tahun 2013). Terdapat tiga karakteristik utama dari PBL. Pertama, PBL merupakan rangkaian aktivitas pembelajaran, artinya dalam kegiatan pembelajaran ada sejumlah kegiatan yang harus dilakukan oleh siswa. Siswa tidak hanya sekedar mendengarkan, mencatat, kemudian manghafal materi pelajaran, akan tetapi melalui PBL akan dilatih untuk aktif berpikir, berkomunikasi, mencari dan mengolah data, dan akhirnya menyimpulkan. Kedua, aktivitas pembelajaran diarahkan untuk menyelesaikan masalah. PBL menempatkan masalah sebagai kata kunci dalam pembelajaran. Ketiga, pemecahan masalah dilakukan dengan menggunakan pendekatan ilmiah yang dilakukan dengan proses berpikir deduktif dan induktif. Proses berpikir ini dilakukan dengan sistematis dan empiris. Sistematis artinya berpikir ilmiah dengan menggunakan tahap-tahap tertentu, sedang empiris artinya proses penyelesaian masalah didasarkan pada data dan fakta yang jelas (Sanjaya, 2008: 214).

Adapun dalam tembang dolanan Padhang Bulan juga mengandung makna religius (keagamaan). Tembang dolanan Padhang Bulan ini selain berisi ajakan untuk bermain bersama yang bertujuan untuk menciptakan suasana yang selaras, seimbang, dan serasi dalam kehidupan bermasyarakat anak-anak. Di samping itu, tembang dolanan ini mampu menunjukkan kekompakan, keakraban,

el Harakah Jurnal Budaya Islam Vol. 19 No.1 Tahun 2017 
kebersamaan, solidaritas, senasib seperjuangan, tenggang rasa, dan membina kerukunan, persahabatan, dan persaudaraan. Contoh perbuatan tolong menolong dapat diberikan kepada anak sebagai bentuk implementasi dalam kehidupan sehari-hari. Lirik ngélingaké aja turu soré-soré 'mengingatkan agar tidak tidur sore' mengandung makna bahwa kita tidak selalu bisa menikmati terang bulan, suasana yang indah dan mengasyikan untuk berkumpul, bercanda ria, bermain, berbagi cerita dan sebagainya. Dengan betah melek kita akan terhindar dari penyakit dan mudah memperoleh rejeki dalam bentuknya yang beragam. Memberi ajakan sederhana kepada anak bahwa sebelum tidur jangan sampai lupa untuk menyelesaikan tugas-tugas sekolah dan menjalankan salat. Jangan sampai mereka tidur di sore hari hingga lupa mengerjakan tugas dan melaksanakan salat.

Berdasarkan uraian di atas, dapat disimpulkan bahwa model pembelajaran Problem Based Learning dapat dilakukan dengan cara mengajak siswa untuk berdialog dan mengomunikasikan mengenai hal-hal sederhana yang mereka lakukan dalam kegiatan sehari-hari seperti bermain, belajar, dsb. Kemudian dari kegiatan tersebut akan muncul beberapa persoalan yang nantinya akan mereka temukan solusinya melalui proses berpikir yang sistematis, empiris, dan sederhana, misalnya melalui pengenalan nilai pendidikan religius dalam lirik tembang dolanan Padhang Bulan.

\section{Simpulan}

Pendidikan karakter religius dapat dipahami sebagai suatu sistem penanaman nilai-nilai karakter religius yang baik kepada semua yang terlibat dan sebagai warga sekolah sehingga mempunyai pengetahuan, kesadaran, dan tindakan dalam melaksanakan nilai-nilai religius tersebut. Melalui pendidikan karakter religius, diharapkan peserta didik mampu secara mandiri meningkatkan dan menggunakan pengetahuannya, mengkaji dan menginternalisasi serta mempersonalisasi nilai-nilai religius dan akhlak mulia sehingga terwujud dalam perilaku sehari-hari. Pendidikan karakter berbasis nilai religius dapat diinternalisasikan dalam kurikulum 2013 melalui model pembelajaran Role Playing, Discovery Learning dan Problem Based Learning dengan pendekatan Saintifik. Bentuk implementasi pendidikan karakter berbasis nilai religius ini dapat tersampaikan secara baik melalui lirik-lirik tembang dolanan. Melalui media ini pesan yang bernilai religius tentu akan lebih mudah tersampaikan khususnya bagi anak-anak. Pendidikan karakter religius tidak hanya diperoleh melalui proses pembelajaran di dalam kelas saja, tetapi juga bisa diperoleh di 
luar kelas, misalnya dengan cara pembelajaran di luar kelas berbasis permainan. Setelah anak mampu memahami arti dan makna pada setiap lirik tembang dolanan, akan lebih mudah mengajak mereka untuk mengimplementasikan nilai-nilai tersebut dalam kehidupan sehari-hari yang dapat dimulai dengan hal-hal kecil dari lingkungan sekitar mereka. Inilah yang disebut dengan implementasi pembelajaran Bahasa Jawa (materi tembang dolanan) berbasis pendidikan karakter religius dalam kurikulum 2013.

\section{Daftar Pustaka}

Arafik. 2013. Penanaman Nilai-Nilai Moral Melalui Tembang Dolanan Sebagai Alternatif Pendidikan Karakter Bagi Anak Usia Dini. Jurnal Pendidikan Anak Usia Dini (PAUD) Universitas Negeri Malang, ISSN: 2338432, Vol 1 , No 2 .

Atika, Surya. 2014. Pelaksanaan Pendidikan Karakter (Religius, Cinta Tanah Air dan Disiplin) di SLB Al Ishlaah Padang. Jurnal Ilmiah Pendidikan Khusus, Volume 3 Nomor 3 Halaman : 747-755.

Azzet, Akmad Muhaimin Azzet. 2011. Urgensi Pendidikan Karakter di Indonesia. Yogyakarta: Ar-Ruzz Media.

Brotosejati, Widodo. 2008. Macapat Teori dan Praktik. Semarang: UNNES Press.

Danandjaja, James. 2007. Folklor Indonesia Ilmu Gosip, Dongeng, dan Lain-lain. Jakarta: Grafiti Press.

Daryanto. 2014. Pendekatan Pembelajaran Saintifik Kurikulum 2013. Yogyakarta: Gava Media.

Fadlillah. 2014. Implementasi Kurikulum 2013 dalam Pembelajaran SD/MI, SMP/ MTS $\mathcal{E}$ SMA/MA. Yogyakarta: Ar-Ruzz Media.

Hidayatullah, M. Furqon. 2010. Pendidikan Karakter: Membangun Peradaban Bangsa. Surakarta: Yuma Pustaka.

Inayati, Khafidlo Fahri Inayati dan Ahmad Sihabul Millah. 2016. Islamic Education and Multiple Intelligences Implementation in Traditional Game of Sluku-Sluku Bathok at Komunitas Pojok Budaya, Bantul of Yogyakarta. Jurnal Pendidikan Islam, Volume 5, Number 1, P-ISSN : 2301 9166; E-ISSN : 2356-3877.

el Harakah Jurnal Budaya Islam Vol. 19 No.1 Tahun 2017 
Jauhari, Hari. 2010. Cara Memahami Nilai Religius dalam Karya Sastra. Bandung: Arfino Raya.

Kementerian Pendidikan Nasional. 2011. Panduan Pelaksanaan Pendidikan Karakter. Jakarta: Badan Penelitian dan Pengembangan Pusat Kurikulum dan Perbukuan.

Keputusan Gubernur Jawa Tengah No: 423.5/27/2011

Majid, Abdul dan Dian Andayani. 2012. Pendidikan Karakter Perspektif Islam. Bandung: PT Remaja Rosdakarya.

Moleong, Lexy J. 2010. Metodologi Penelitian Kualitatif. Bandung: PT Remaja Rosdakarya.

Mulyana, Deddy. 2007. Metodologi Penelitian Kualitatif: Paradigma Baru Ilmu Komunikasi dan Ilmu Sosial Lainnya. Bandung: PT Remaja Rosdakarya.

Mulyasa, E. 2011. Manajemen Pendidikan Karakter. Jakarta: Bumi Aksara.

Muslich, Masnur. 2011. Pendidikan Karakter: Menjawab Tantangan Krisis Multidimensional. Jakarta: PT Bumi Aksara.

Nugrahani, Farida. 2012. Reaktualisasi Tembang Dolanan Jawa dalam Rangka Pembentukan Karakter Bangsa (Kajian Semiotik). Jurnal Kajian Linguistik dan Sastra, Vol. 24, No. 1, Juni 2012: 58-68.

Permendikbud Nomor 20 Tahun 2016 Tentang Standar Kompetensi Lulusan Pendidikan Dasar dan Menengah.

Permendikbud Nomor 21 Tahun 2016 Tentang Standar Isi Pendidikan Dasar dan Menengah.

Permendikbud Nomor 65 Tahun 2013 Tentang Standar Proses Pendidikan Dasar dan Menengah.

Permendikbud Nomor 81a Tahun 2013 Tentang Implementasi Kurikulum.

Prastowo, Andi. 2013. Pengembangan Bahan Ajar Tematik. Yogyakarta: DIVA Press.

Purwadi. 2010. Diktat Seni Tembang I. Yogyakarta: FBS UNY. 
Samani, Muchlas dan Hariyanto. 2013. Konsep dan Model Pendidikan Karakter. Bandung: PT Remaja Rosdakarya.

Samsuri. 2011. Pendidikan Karakter Warga Negara. Yogyakarta: Diandra

Sanjaya. 2008. Strategi Pembelajaran Berorientasi Standar Proses Pendidikan. Jakarta: Kencana Prenada Media Group.

Supriadi, Didik. 2010. Transformasi Lelagon Dolanan Klasik ke Lelagon Dolanan Kreasi Baru. Semarang: Skripsi Universitas Negeri Semarang.

Uno, Hamzah B. 2008. Model Pembelajaran. Jakarta: Bumi Aksara.

Vikiyono, Derit. 2015. Implementasi Pendidikan Karakter di SDIT Qurrota A'yun Ponorogo. Surakarta: Program Pascasarjana Universitas Sebelas Maret.

Wibowo, Agus. 2013. Pendidikan Karakter Berbasis Sastra. Yogyakarta: Pustaka Pelajar.

Wiyani, Novan Ardy. 2013. Konsep, Praktik, dan Strategi Membumikan Pendidikan Karakter di SD. Yogyakarta: Ar-Ruzz Media. 
